species, indicating a habitat that could support grazing mammals ${ }^{10}$.

The GRIP core seemed to corroborate a difference between Holocene climate and that of previous interglacials by showing major fluctuations within the 'last interglacial' around $120 \mathrm{kyr}$. The veracity of this part of the core has been questioned, however: the 'fluctuations' may be due to folding; moreover, they are not seen in some other ice-core and oceanic sequences ${ }^{11}$. On the other hand, independent lines of evidence corroborate Eemian inconstancy, including data from the crucial terrestrial realm. Data from a lake core in France $^{2}$ indicate two rapid cooling events within the last interglacial, including a period of reversion from forest to open subalpine vegetation. Analysis of detailed pollen records from Germany ${ }^{3}$ suggests greater climatic instability in the last interglacial than in the Holocene. Finally, evidence of mid-Eemian cooling has come from studies in the Norwegian Sea and North Atlantic Ocean ${ }^{4}$.
The spatial structure of the terrestrial interglacial environment requires further investigation, as does the mammoths' response to it, which clearly varied across their vast range. A crucial role may have been played by unglaciated Arctic regions in providing interglacial refuges for the tundra-steppe grazers. This pattern was again followed at the start of the Pleistocene/Holocene transition, which seems to have begun as a 'normal' interglacial. However, subsequent changes, culminating in the onset of stable climate documented by the ice cores, resulted in an irreversible turnover of the Pleistocene biota.

\section{Adrian M. Lister}

Department of Biology,

University College London,

London WC1E 6BT, UK

Andrei V. Sher

Severtsov Institute of Ecology and Evolution,

Russian Academy of Sciences, Moscow 117071, Russia

\title{
ESR ages for Krapina hominids
}

SIR - At the site of Krapina, $40 \mathrm{~km}$ NNW of Zagreb, more than 850 skeletal remains from several Neanderthal individuals were found, principally in layers 3 and 4 (refs 1, 2), associated with a Middle Palaeolithic industry ${ }^{3}$. We have obtained electron spin resonance $(\mathrm{ESR})^{4}$ and U-series dates on tooth enamel from the site (see table). Teeth from the 1899-1905 archaeological excavations of K. Gorjanoviĉ-Kramberger, stored at the Croatian Natural History Museum, were analysed as in ref. 4. External $\gamma$ and $\beta$-dose rates were estimated from $U$, Th and $\mathrm{K}$ analyses of blocks of weakly indurated sand preserved from the

\begin{tabular}{|c|c|c|c|c|c|c|c|}
\hline \multicolumn{8}{|c|}{ ESR AND U-SERIES DATES FOR KRAPINA } \\
\hline \multirow[t]{2}{*}{ Layer } & \multirow[t]{2}{*}{ Sample } & \multicolumn{3}{|c|}{ ESR age (kyr) } & \multicolumn{3}{|c|}{ U-series age (kyr) } \\
\hline & & Early uptake & Average & Linear uptake & Average & Enamel & Dentine \\
\hline 9 & $91187 A$ & $87 \pm 7$ & $87 \pm 7$ & $113 \pm 10$ & $113 \pm 10$ & & \\
\hline 8 & $\begin{array}{l}91182 \mathrm{~A} \\
91182 \mathrm{~B} \\
91182 \mathrm{C} \\
91182 \mathrm{D} \\
91182 \mathrm{E} \\
91182 \mathrm{G} \\
91182 \mathrm{H} \\
91182 \mathrm{I}\end{array}$ & $\begin{array}{c}109 \pm 9 \\
90 \pm 8 \\
88 \pm 7 \\
90 \pm 6 \\
94 \pm 6 \\
88 \pm 8 \\
93 \pm 9 \\
90 \pm 10\end{array}$ & & $\begin{array}{l}147 \pm 14 \\
120 \pm 12 \\
122 \pm 11 \\
126 \pm 11 \\
128 \pm 11 \\
120 \pm 11 \\
130 \pm 12 \\
123 \pm 13\end{array}$ & & & \\
\hline $7-8$ & $\begin{array}{l}91183 \mathrm{~A} \\
91183 \mathrm{~B} \\
91183 \mathrm{C} \\
91183 \mathrm{D} \\
91183 \mathrm{E} \\
91183 \mathrm{~F} \\
91183 \mathrm{G} \\
91183 \mathrm{H} \\
91184\end{array}$ & $\begin{array}{c}108 \pm 9 \\
96 \pm 8 \\
94 \pm 7 \\
94 \pm 7 \\
95 \pm 8 \\
103 \pm 9 \\
100 \pm 8 \\
102 \pm 8 \\
131 \pm 13\end{array}$ & $99 \pm 5$ & $\begin{array}{l}139 \pm 14 \\
128 \pm 12 \\
127 \pm 12 \\
128 \pm 12 \\
126 \pm 12 \\
135 \pm 13 \\
132 \pm 13 \\
135 \pm 13 \\
152 \pm 17\end{array}$ & $132 \pm 5$ & $69.7 \pm 0.5$ & $89.8 \pm 1.4$ \\
\hline $5-6$ & $\begin{array}{l}91186 A \\
93042 A \\
93042 B\end{array}$ & $\begin{array}{l}126 \pm 11 \\
132 \pm 13 \\
132 \pm 14\end{array}$ & $130 \pm 3$ & $\begin{array}{l}178 \pm 17 \\
160 \pm 18 \\
162 \pm 19\end{array}$ & $167 \pm 10$ & $131 \pm 1$ & $\begin{array}{l}223 \pm 4 \\
415_{-38}^{+55}\end{array}$ \\
\hline 1 & $\begin{array}{l}91185 A \\
91188 A \\
91189 A\end{array}$ & $\begin{array}{l}142 \pm 12 \\
142 \pm 11 \\
116 \pm 9\end{array}$ & $133 \pm 15$ & $\begin{array}{l}185 \pm 19 \\
192 \pm 18 \\
163 \pm 16\end{array}$ & $180 \pm 15$ & & \\
\hline
\end{tabular}

ESR dates are computed assuming $10 \pm 10 \%$ water in sediment. $\gamma$ - And $\beta$-doses from sediment were determined from neutron activation analyses of sediment samples for $U$. Th and $\mathrm{K}$. $\beta$-doses were corrected for attenuation. U-series ages were determined by thermal ionization mass spectrometry ${ }^{5}$. original excavation, found at the museum.

We used mass spectrometric U-series analysis of the enamel and dentine to evaluate U-uptake history, which affects the calculated ESR age ${ }^{5}$. Early uptake yields the minimum age for a given data set, while linear-uptake ages commonly agree with other age estimates. Equivalent early-uptake ages and U-series ages in teeth from layers 5-6 indicated early U-uptake, whereas early-uptake ages of teeth from layers 7-8 were larger than associated U-series dates, implying continuous $U$ uptake. The respective linear-uptake or early-uptake ages of teeth from layers 1-8 were indistinguishable, with a mean of $130 \pm 10 \mathrm{kyr}$, showing that the entire fluviatile sequence was formed in the last interglacial (stage 5e), consistent with its faunal character.

Whereas hominids from beds 3-7 are all Neanderthals, layer 8 (also dated to $130 \mathrm{kyr}$ ) contained cranial elements of a 6-8-yr-old juvenile (Krapina 1). Some metric and morphological aspects group it with other juvenile Neanderthals, but its more pentagonal shape in rear view, higher frontal squama and some other characteristics approach the condition of early modern humans (N. Minugh-Purvis, unpublished thesis, Univ. Pennsylvania). A partial occipital bone from layer 8 (Krapina 11) lacks a suprainiac fossa, a characteristic of Neanderthals observed in occipitals from layers 3-4. These data suggest that the layer 8 hominids are possibly transitional to anatomically modern hominids, raising the question of when this taxon first appeared in Europe.

W. J. Rink

\section{H. P. Schwarcz}

Department of Geology,

McMaster University, Hamilton,

Ontario L8S 4M1, Canada

F. H. Smith

Department of Anthropology,

Northern Illinois University,

Dekalb, Illinois 60115, USA

J. Radovĉić

Croatian Natural History Museum

Demetrova 1, 1000 Zagreb, Croatia

1. Smith, F. in The Origins of Modern Humans (eds Smith, F. H. \& Spencer, F.) 137-209 (Liss, New York, 1984).

2. Gorjanović-Kramberger, D. Der diluviale Mensch von Krapina in Kroatien: Ein Beitrag zur Paläoanthropologie (Kriedel, Wiesbaden, 1906).

3. Simek, J. in Raw Material Economies Among Prehistoric Hunter Gatherers (eds Montet-White, A. \& Holen, S.) 59-71 (Univ. Kansas Publs Anthropology, Lawrence, KS 1991).

4. Grün, R., Schwarcz, H. P. \& Zymela, S. Can. J. Earth Sci. 24, 1022-1037 (1987)

5. Grün, R., Schwarcz, H. P. \& Chadam, J. J. nucl. Tracks Radiat. Measmt 14, 237-241 (1988).

\section{Scientific Correspondence}

Scientific Correspondence is intended to provide a forum in which readers may raise points of a scientific character. Priority will be given to letters of fewer than 500 words and five references. 